\title{
Effect of Heat on Nutrition of Solanum tuberosum
}

\author{
M. A. Rashid*, Md. Iqbal Hussain, M. Saifullah, M. A. Habib, M. A. Sattar \\ Department of Applied Chemistry and Chemical Technology, Islamic University, Kushtia, Bangladesh \\ Email: *mamunacctiu@gmail.com
}

Received 18 February 2016; accepted 7 August 2016; published 10 August 2016

Copyright (C) 2016 by authors and OALib.

This work is licensed under the Creative Commons Attribution International License (CC BY).

http://creativecommons.org/licenses/by/4.0/

(c) (i) Open Access

\begin{abstract}
Various nutritional values are more influenced by cooking than others. This study compared the effects of microwave heating with conventional cooking method of fresh Potato (Solanum tuberosum). The moisture and ash content in raw potato were $76.60 \%$ and $0.40 \%$, respectively. After conventional cooking moisture and ash content were $\mathbf{7 8 . 0 0 \%}$ and $0.50 \%$, respectively and after microwave heating it saw the values were $77.20 \%$ and $0.60 \%$, respectively. The fat and carbohydrate content in raw potato were $0.70 \%$ and $20.46 \%$, respectively. After conventional cooking those values were $0.80 \%$ and $19.40 \%$, respectively and in microwave heating it showed the values were $0.50 \%$ and $20.08 \%$, respectively. Total protein content was also changed by those cooking methods. In microwave heating it reduced the vitamin-C content to some extent but the conventional cooking completely destroyed the vitamin- $C$ contents.
\end{abstract}

\section{Keywords}

Nutrient, Vegetable, Conventional Cooking, Heating, Solanum tuberosum

Subject Areas: Food Science \& Technology

\section{Introduction}

Cooking is the domestic processing method of food nutrients, usually, vegetables are processed at home on the basis of convenience and taste preference [1]. It affects significant changes in chemical composition, bioavailability and content of chemopreventive compounds in potato. Cooking methods affect the contents of nutrient and health-promoting compounds [2]-[5]. The cooking procedures (such as boiling and microwaving) were based on the dietary habit.

Potato is one of the most important food legume crops in the semi-arid tropics covering Asia, Africa, Southern Europe and Central and South America. A drought-tolerant and warm-weather crop potato is well-grown to

${ }^{*}$ Corresponding author.

How to cite this paper: Rashid, M.A., Hussain, M.I., Saifullah, M., Habib, M.A. and Sattar, M.A. (2016) Effect of Heat on Nutrition of Solanum tuberosum. Open Access Library Journal, 3: e2490. http://dx.doi.org/10.4236/oalib.1102490 
the drier regions of the tropics, where other food legumes do not perform well. It also has the useful ability to fix atmospheric nitrogen through its root nodules, and it grows well in poor soils with more than $85 \%$ sand and with less than $0.2 \%$ organic matter and low levels of phosphorus [6].

Nutritional science supplies metabolic and physiological responses of the body to diet. It is food science and the processes through which humans ingest, absorb, transport, utilize, and excrete food substances. With advances in the fields of molecular biology, biochemistry and genetics, the study of nutrition is increasingly concerned with metabolism and metabolic pathways: the sequences of biochemical steps through which substances in living things change from one form to another. This study tried to reveal a suitable cooking method which will help to provide us more nutrient rich cooked food by comprising conventional cooking and microwave cooking method so that it is possible to overcome the nutrient lacking problems.

\section{Materials and Methods}

\subsection{Preparation of Sample}

Fresh potatob (Solanum tuberosum) was collected from local market Lauri, Monirampur, Jessore, Bangladesh. Samples were washed properly and cut into small sizes.

\subsection{Conventional Cooking}

From various methods of conventional cooking, boiling method was applied in the research for the cooking. In this, the sample was just immersed in $100^{\circ} \mathrm{C}$ water and the water was maintained at that temperature untill the sample was tendered.

\subsection{Microwave Cooking}

A weighed, chopped sample was taken in a beaker. The sample in the microwave oven was cooked (about $45 \mathrm{~s}$ in a $700 \mathrm{~W}$ oven). Removing the sample from the oven the nutrition values were computed.

\subsection{Determination of Moisture Content}

Moisture was estimated by drying method. A crucible was dried to a constant weight in air oven at $110^{\circ} \mathrm{C}$ and weighed (W1). Two grams of finely ground sample was weighed into the previously labeled crucible and reweighed (W2). The crucible containing the sample was dried in an oven to constant weight (W3). The percentage moisture content was calculated as follows:

$$
\% \text { Moisture content }=\frac{(\mathrm{W} 2-\mathrm{W} 3) \times 100}{\mathrm{~W} 2-\mathrm{W} 1}
$$

\subsection{Determination of Ash Content}

For the determination of ash, a clean porcelain crucible was dried in an oven at $100^{\circ} \mathrm{C}$ for $10 \mathrm{~min}$, cooled in a desiccator and weighed (W1). Two grams of the finely ground sample was placed into a previously weighed porcelain crucible and reweighed (W2), it was first ignited and then transferred into a furnace which was set at $550^{\circ} \mathrm{C}$. The sample was left in the furnace for eight hours to ensure proper ashing. The crucible containing the ash was then removed; cooled in a desiccator and weighed (W3). The percentage ash content was calculated as follows:

$$
\% \text { Ash content }=\frac{(\mathrm{W} 3-\mathrm{W} 1) \times 100}{\mathrm{~W} 2-\mathrm{W} 1}
$$

\subsection{Determination of Crude Protein Content}

Protein in the sample was determined by Kjeldahl method [7]. $2 \mathrm{~g}$ of dried samples was taken in digestion flask. Add 10 - $15 \mathrm{ml}$ of concentrated $\mathrm{H}_{2} \mathrm{SO}_{4}$ and $8 \mathrm{~g}$ of digestion mixture i.e. $\mathrm{K}_{2} \mathrm{SO}_{4}: \mathrm{CuSO}_{4}$ (8:1). The flask was swirled in order to mix the contents thoroughly then placed on heater to start digestion till the mixture become clear (blue green in color). It needs 2 hrs to complete. The digest was cooled and transferred to $100 \mathrm{ml}$ volumetric flask and volume was made up to mark by the addition of distilled water. Distillation of the digest was performed 
in Markam Still Distillation Apparatus [8]. Ten milliliters of digest was introduced in the distillation tube then $10 \mathrm{ml}$ of $0.5 \mathrm{NNaOH}$ was gradually added through the same way. Distillation was continued for at least $10 \mathrm{~min}$ and $\mathrm{NH}_{3}$ produced was collected as $\mathrm{NH}_{4} \mathrm{OH}$ in a conical flask containing $20 \mathrm{ml}$ of $4 \%$ boric acid solution with few drops of modified methyl red indicator. During distillation yellowish color appears due to $\mathrm{NH}_{4} \mathrm{OH}$. The distillate was then titrated against standard $0.1 \mathrm{~N} \mathrm{HCl}$ solution until the appearance of pink color. A blank was also run through all steps as above. Percent crude protein content of the sample was calculated by using the following equation:

\% Protein

$=6.25 \times \frac{(\text { Sample Titration }- \text { Blank Titration }) \times \text { Strength of } \mathrm{HCl} \times 0.014 \times \text { Volume of digest Sample } \times 100}{\text { Wt. of the sample } \times \text { Volume taken for Distillation }}$

\subsection{Determination of Crude Fat}

The fat content was calculated by ether extract method using Soxhlet apparatus [9]. Since all the fat materials e.g. fats, phospholipids, sterols, fatty acids, carotenoids, pigments, chlorophyll etc. are extracted together therefore, the results are frequently referred to as crude fat. Approximately $1 \mathrm{~g}$ of moisture free sample was wrapped in filter paper, placed in fat free thimble and then introduced in the extraction tube. Weighed, cleaned and dried the receiving beaker was filled with petroleu mether and fitted into the apparatus. Turned on water and heater to start extraction. After 4 - 6 siphoning allow ether to evaporate and disconnect beaker before last siphoning. Transferred extract into clean glass dish with ther washing and evaporated ether on water bath. Then placed the dish in an oven at $105^{\circ} \mathrm{C}$ for $2 \mathrm{hrs}$ and cooled it in a desiccator. The percent crude fat was determined by using the following formula:

$$
\% \text { Fat content }=\frac{\text { Wt. of Ether Extract } \times 100}{\text { Wt. of Sample }}
$$

\subsection{Determination of Carbohydrate}

The total carbohydrate was calculated by distinction. The summation of the percentage moisture, ash, crude protein and crude fat was deducted from 100 [10].

$$
\% \text { Carbohydrate }=100-(\text { moisture content }+ \text { ash content }+ \text { protein content }+ \text { fat content }) \%
$$

\subsection{Determination of Vitamin C}

Vitamin C content was calculated according to the Association of Official Analytical Chemists (AOAC) Official Method 985.33 (2, 6-dichloroindophenol titrimetric method) [11]. Vitamin C content is denoted as mg/100 g fresh weight.

\subsection{Experimental Design and Statistical Analysis}

The nutrient contents from the sample were estimated in triplicate, and mean values were calculated. A Student's t-test was computed for the statistical significance of the results.

\section{Results and Discussion}

Food making is a significant step in meeting the nutritional demands. Cooking affects food nutrients significantly. Most nutrients are mainly absorbed in cooking and which affects the human body. In this study it showed changes brought by cooking (microwave and conventional method) in the nutrient content of one fresh vegetables collected from local area named as potato.

Previously showed that fresh samples of potato remained $76.60 \%$ moisture, $0.70 \%$ fat, $1.84 \%$ protein, $20.46 \%$ carbohydrate. In this study, the moisture content in fresh potato was $76.60 \%$. In conventional cooking moisture content in potato was $78 \%$ whereas in microwaving $77.20 \%$ was found for potato (Figure 1). Ash content in fresh potato was $0.40 \%$, but after conventional and microwave cooking it was found $0.50 \%$ and $0.60 \%$, respectively (Figure 2). 


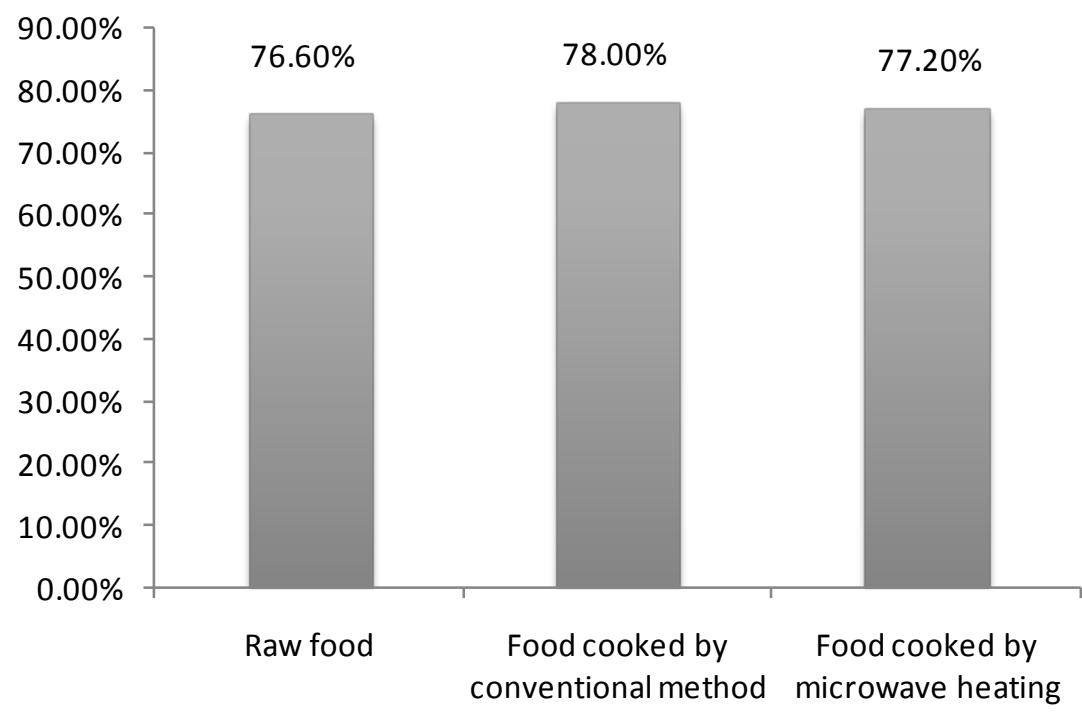

Figure 1. Change of moisture content in Solanum tuberosum.

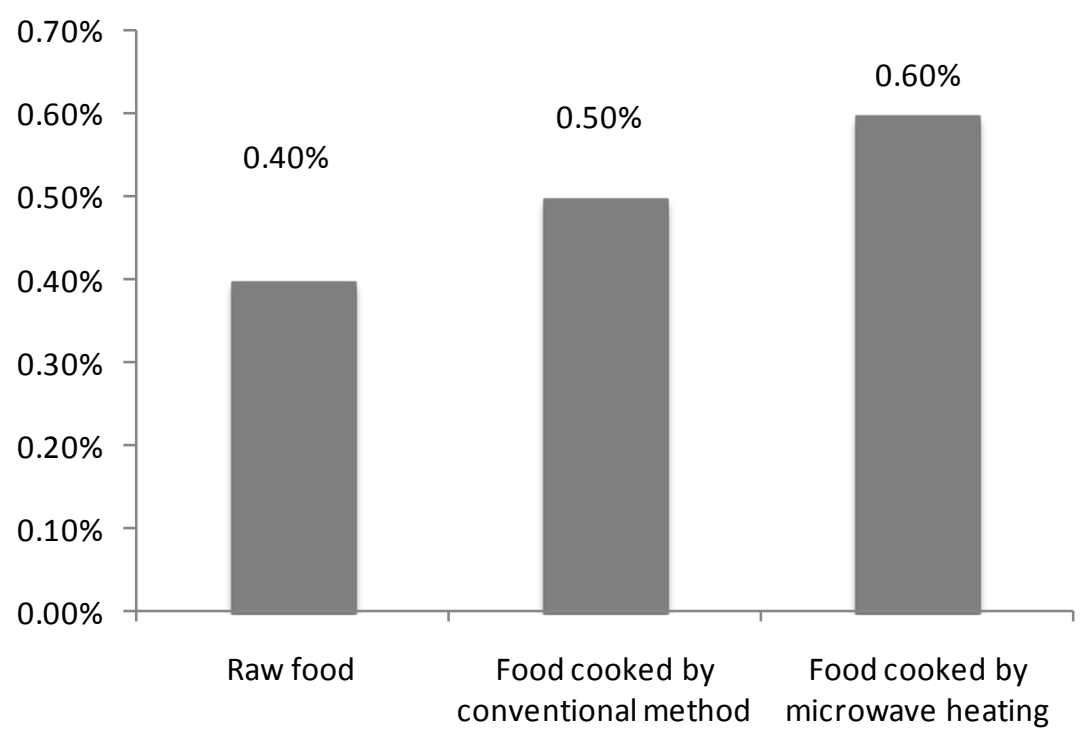

Figure 2. Change of ash content in Solanum tuberosum.

Total crude protein of fresh potato was 1.84\%. After conventional and microwave cooking it was found $1.23 \%$ and $1.81 \%$, respectively (Figure 3). As shown in Figure 4, crude fat in fresh potato was $0.70 \%$. After doing conventional and microwave cooking it was obtained $0.80 \%$ and $0.50 \%$, respectively.

The carbohydrate content in fresh potato was $20.46 \% .19 .40 \%$ carbohydrate was found in potato after conventional cooking while $20.08 \%$ carbohydrate was found after microwave cooking (Figure 5).

Vitamin C is one of the most important nutritional factors in the human body [12]. The concentration of ascorbic acid (the predominant form of vitamin C) in fresh vegetables generally decreased after cooking [13]. Both cooking treatments caused a dramatic loss of vitamin C. $0.23 \%$ of vitamin C was observed in raw potato. After microwaving $0.17 \%$ was observed in potato while conventional cooking completely destroyed the vitamin-C in potato (Figure 6).

\section{Conclusion}

Bangladesh is a developing country. As a result many people of this country are suffered nutritionally. For this 


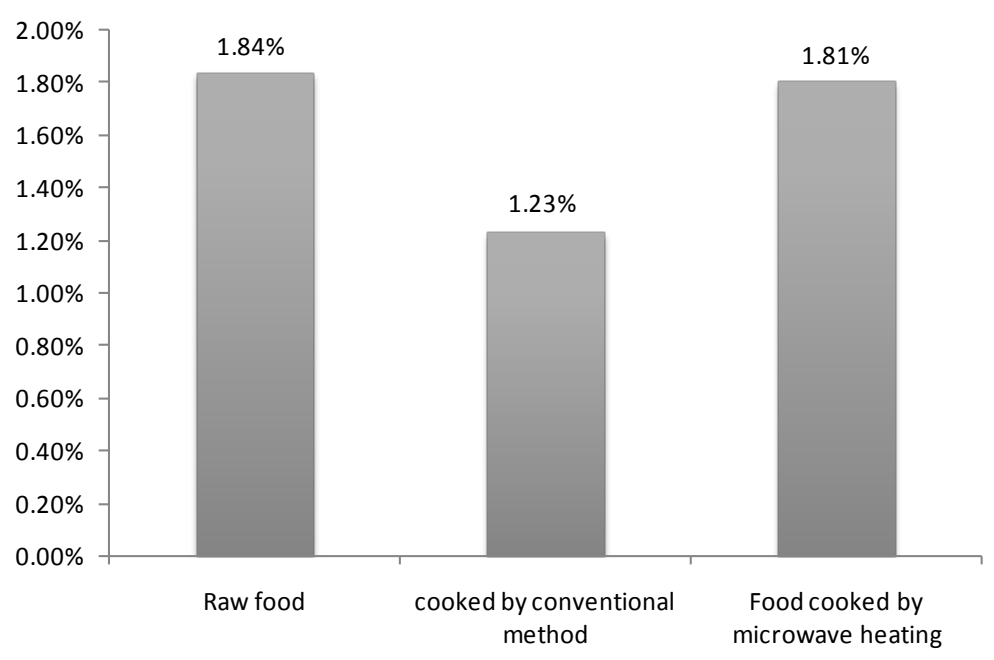

Figure 3. Change of Protein content in Solanum tuberosum.

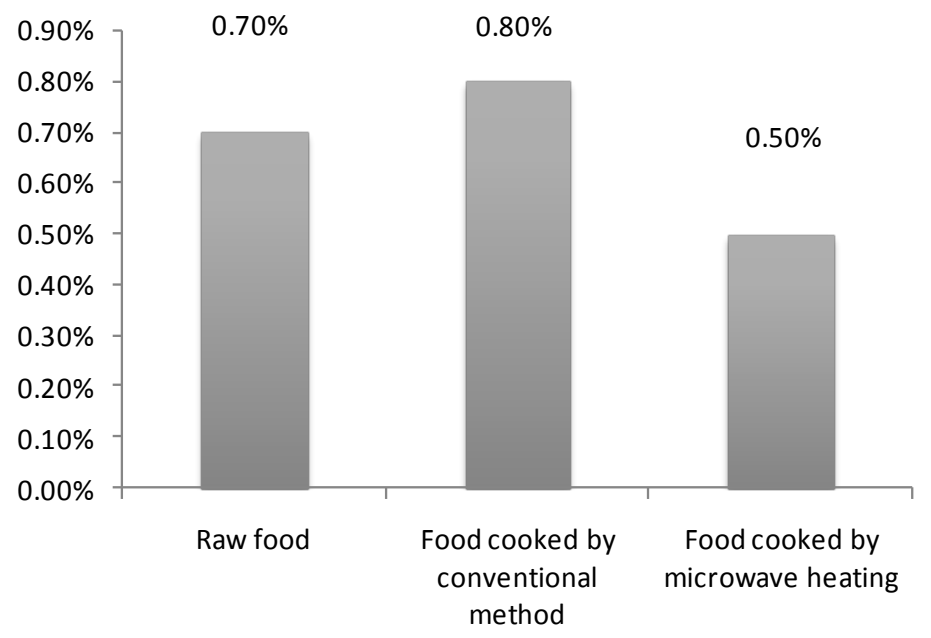

Figure 4. Change of fat content in Solanum tuberosum.

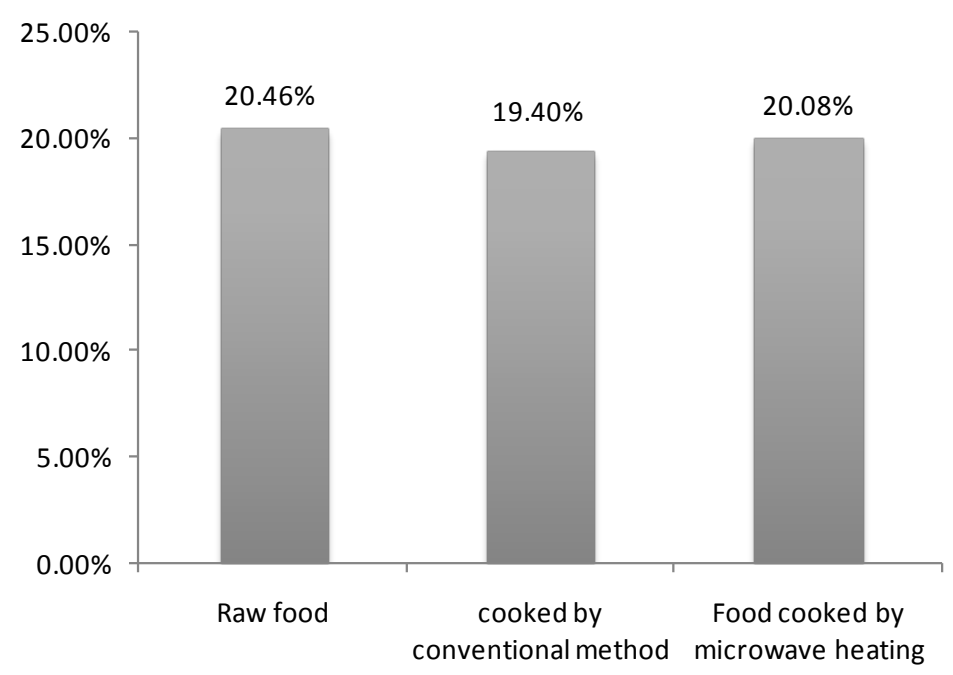

Figure 5. Change of carbohydrate content in Solanum tuberosum. 


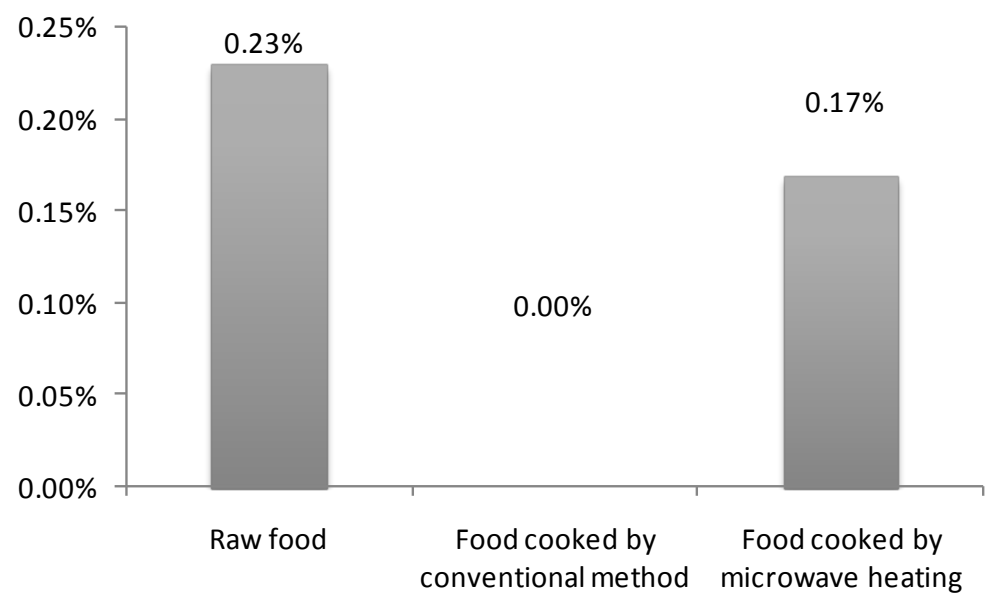

Figure 6. Change of vitamin C content in Solanum tuberosum.

reason people should prefer better cooking method by which nutrient contents are obtained very much. Microwave cooking method is preferred to other methods because microwave cooked food obtains high amount of nutritional values.

\section{References}

[1] Masrizal, M.A., Giraud, D.W. and Driskell, J.A. (1997) Retention of Vitamin C, Iron, and Beta-Carotene in Vegetables Prepared Using Different Cooking Methods. Journal of Food Quality, 20, 403-418. http://dx.doi.org/10.1111/j.1745-4557.1997.tb00483.x

[2] Cieslik, E., Leszczynska, T., Filipiak-Florkiewicz, A., Sikora, E. and Pisulewski, P.M. (2007) Effects of Some Technological Processes on Glucosinolate Contents in Cruciferous Vegetables. Food Chemistry, 105, 976-981. http://dx.doi.org/10.1016/j.foodchem.2007.04.047

[3] Lin, C.H. and Chang, C.Y. (2005) Textural Change and Antioxidant Properties of Broccoli under Different Cooking Treatments. Food Chemistry, 90, 9-15. http://dx.doi.org/10.1016/j.foodchem.2004.02.053

[4] Sikora, E., Cieslik, E., Leszczynska, T., Filipiak-Florkiewicz, A. and Pisulewski, P.M. (2008) The Antioxidant Activity of Selected Cruciferous Vegetables Subjected to Aquathermal Processing. Food Chemistry, 107, 55-59. http://dx.doi.org/10.1016/j.foodchem.2007.07.023

[5] Vallejo, F., Tomas-Barberan, F.A. and Garcia-Viguera, C. (2002) Glucosinolates and Vitamin C Content in Edible Parts of Broccoli Florets after Domestic Cooking. European Food Research and Technology, 215, 310-316. http://dx.doi.org/10.1007/s00217-002-0560-8

[6] Singh, B. (2003) Improving the Production and Utilization of Cowpea as Food and Fodder. Field Crops Research, 84, 169-150.

[7] Williams, K.A. (1966) Oils, Fats and Fatty Foods. J \& A. Churchil Ltd., London, (4), 136.

[8] Khalil, I.A. and Manan, F. (1990) Text Book of Chemistry I. Bio.Analytical Chemistry. 2nd Edition, TajKutabKhana, Peshawar.

[9] AOAC (1984) Official Methods of Analysis of AOAC International. 18th Edition, A.O.A.C. International, Gaithersburg, MD.

[10] Muller, H.G. and Tobin, G. (1980) Nutrition and Food Processing. Croom Helm, London.

[11] AOAC (Association of Official Analytical Chemists) (1990) Official Method 985.33. Vitamin C (Reduced Ascorbic Acid) in Ready-to-Feed Milk-Based Infant Formula 2,6-Dichloroindophenol Titrimetric Method. In: Official Methods of Analysis, AOAC International, Washington DC, 1108-1109.

[12] Lee, S.K. and Kader, A.A. (2000) Preharvest and Postharvest Factors Influencing Vitamin C Content of Horticultural Crops. Postharvest Biology and Technology, 20, 207-220. http://dx.doi.org/10.1016/S0925-5214(00)00133-2

[13] Serrano, M., Martinez-Romero, D., Guillen, F., Castillo, S. and Valero, D. (2006) Maintenance of Broccoli Quality and Functional Properties during Cold Storage as Affected by Modified Atmosphere Packaging. Postharvest Biology and Technology, 39, 61-68. http://dx.doi.org/10.1016/j.postharvbio.2005.08.004 